\title{
Prevalence and severity of anemia among school children in Jimma Town, Southwest Ethiopia
}

\author{
Selomon Assefa ${ }^{1+}$, Andualem Mossie $^{2^{*}}$ and Leja Hamza ${ }^{3+}$
}

\begin{abstract}
Background: Anemia is a major health problem worldwide. Because of health and socioeconomic problems, the prevalence of anemia is higher in developing countries. Children and pregnant women are the most vulnerable groups to anemia. The aim of the present study was to determine the magnitude of anemia among school children.

Methods: A cross-sectional household survey was conducted in January 2011 on 423 children, aged 6-14 years, selected through systematic random sampling method. Sociodemographic and anthropometric data were collected using a pre-tested questionnaire. Capillary blood was taken from the fingertip of each child and hemoglobin was measured using HaemoCue digital photometer. All the necessary safety measures were taken during blood collection. Anthropometric indicators were measured using WHO's guideline. Data analysis was made using SPSS Version 16.0 for Windows. The association between predictors and outcome variables were measured by a stepwise logistic regression model. Ethical permission was obtained; consent of the parents/guardian was taken and confidentiality was maintained.

Result: A total of 404 children were studied. The mean age was 10.21(SD \pm 1.89$)$ years. The proportion of females was $217(53.7 \%)$. The mean hemoglobin level for both sexes was $11.59(\mathrm{SD} \pm 1.97 \mathrm{~g} / \mathrm{dl})$. The current prevalence of anemia was 152(37.6\%), out of which, 73(18.1\%) had mild while 79(19.6\%) of them had moderate anemia. The prevalence of anemia among the age group of 6-11 years was 118(40.5\%) while the prevalence among the group of 12-14 years old children was 34(30.1\%). Among the selected variables in the logistic regression analysis, low family income $[\mathrm{OR}=4.925,95 \% \mathrm{Cl}(1.063,22.820)]$, mothers' education $[\mathrm{OR}=4.621,95 \% \mathrm{Cl}(1.383,15.439)]$, intake of plant food $[\mathrm{OR}=3.847,95 \% \mathrm{Cl}(2.068,7.157)]$ and intake of animal food $[\mathrm{OR}=2.37,95 \% \mathrm{Cl}(1.040,5.402)]$ were significantly and independently associated with anemia.

Conclusion: Anemia is a moderate public health problem in the study area. Family income, educational status of parents and inadequate plant and animal food intake are the predictors of anemia. Improving the economic status of the family, women education and health education about balanced animal and plant food consumption are recommended strategies to reduce the burden of anemia.
\end{abstract}

Keywords: Hemoglobin, Anemia, School children, Prevalence

\section{Background}

'Anemia' refers to a condition in which the hemoglobin content of the blood is lower than normal as a result of deficiency of one or more essential nutrients [1], heavy blood loss, parasitic infections and congenital hemolytic diseases [2].

\footnotetext{
* Correspondence: andualemm2000@gmail.com

${ }^{\dagger}$ Equal contributors

${ }^{2}$ Associate Professor (PhD, Physiologist), Department of Biomedical Sciences, College of Public Health and Medical Sciences, Jimma University, Jimma, Ethiopia

Full list of author information is available at the end of the article
}

Globally, anemia is a public health problem affecting people in both developed and developing countries with bad consequences of human health as well as social and economic development $[3,4]$. Anemia is a critical health concern because it affects growth and energy levels adversely [2]. It damages immune mechanisms and is also associated with increased morbidity [3]. It occurs at all age groups, but is more prevalent in pregnant women and children [2]. Especially, young children from low income families have a higher risk for developing anemia

\section{Biomed Central}

(c) 2014 Assefa et al.; licensee BioMed Central Ltd. This is an open access article distributed under the terms of the Creative Commons Attribution License (http://creativecommons.org/licenses/by/2.0), which permits unrestricted use, distribution, and reproduction in any medium, provided the original work is properly cited. 
due to iron deficiency that occurs as a result of high demand for iron during the period of rapid growth [5].

Globally, anemia affects 1.62 billion (24.8\%) of the population [4], and an estimated 36\% of developing world's population suffers from this disease [6]. Anemia is known to be a significant global problem affecting 305 million (25.4\%) school age children (SAC) [4].

In developing countries, the prevalence of anemia among school age children is $40 \%$, and it is classified as severe public health problem $[2,4]$. The problem is alarming in Sub-Saharan African Countries such as Kenya 48.9\% [7]; Mali 55.8\% [8] and Tanzania 79.6\% [9]. Lack of awareness among the mothers about the problem coupled with their low educational status [10], poor nutritional practices and unhealthy food habits [11], low iron bioavailability of the diet [12], decreased physical activities [13], malaria and parasitic infestations are additional factors associated with lower hemoglobin $(\mathrm{Hb})$ level in children [14].

Although anemia remains a widespread public health problem in most developing countries, and even developed countries, there are very few studies on the prevalence and severity of anemia among school age children in Jimma area, Ethiopia. Because of its impact on cognitive development and physical growth, studies on the magnitude of anemia among school age children have paramount importance. Anemia creates long term effects among female children resulting in low birthweight babies and post partum hemorrhage. Therefore, the main aim of the present study was to determine the prevalence and severity of anemia on school children.

\section{Methods}

\section{Study design}

A cross-sectional community-based study was conducted among children aged 6 to 14 years in January 2011 in Jimma Town, 354 kilometers southwest of Addis Ababa, Ethiopia. According to the 2007 population and housing census of Ethiopia, the projected total population of Jimma Town in 2010 was 132,052 (Men = 66,343 and Women = 65,708). According to the Office of Education in Jimma Town, there are a total of 24,993 school age children in the town [15]. The sample size of 423 was determined using single population proportion formula. To maximize the sample size, prevalence of anemia (50\%) was considered. Ninety five percent certainty and 5\% margin of error was taken. Ten percent non-response rate was added to the sample size as a contingency.

\section{Sampling technique}

Systematic random sampling technique was used to select the study participants. Four kebeles were selected randomly out of a total of 13 kebeles of Jimma Town. Kebele is the smallest administrative unit in the governmental structure in Ethiopia. The number of samples taken from each kebele was allocated proportionally. From the selected four kebeles, every 8th household was included in the survey. To start the interview, the first household was selected based on house numbering sequence. One child aged from 6 to 14 years was included from each selected household. If there were more than one child in a household, one was taken for an interview by a lottery method.

\section{Method of data collection}

Sociodemographic data were collected using pre-tested structured questionnaire. Dietary variables were collected using a simplified food frequency questionnaire (FFQ), which is the modified version of Helen Keller International FFQ. This questionnaire has been adopted in Ethiopia, to estimate consumption of foods from animal and plant sources [16].

\section{Blood test}

Portable hemoglobinometer (HemoCue AB, Angelhom, Sweden) was used to determine hemoglobin concentration from a capillary blood sample collected from the fingertip of each child aseptically, using sterile single-use disposable lancet. It was done by trained and experienced laboratory technicians. The necessary safety measures were taken during blood collection. Seventy percent ethanol alcohol was used as disinfectant.

\section{Anthropometric measurements}

Measurements of height and weight were taken according to the WHO's guideline [17]. Important anthropometric indicators were height-for-age z-scores (HAZ) and BMI $\mathrm{z}$-scores (BMIZ). Weight-for-age z-scores is not a good indicator for children age above 10 years. Because of the pubertal growth surge in children above 10 years, weightfor-age was assessed by BMI-for-age [18].

\section{Methods of data analysis}

Statistical package for the Social Science (SPSS) Version 16.0 for Windows was used for data analysis. Chi-square test and stepwise logistic regression model analysis were carried out to assess the association between independent and outcome variables. $\mathrm{P} \leq 0.05$ was taken as a minimum level of significance.

\section{Operational definitions}

Anemia was defined in accordance with the WHO standard for children. Accordingly, anemia is defined as $\mathrm{Hb}$ level below $12 \mathrm{~g} / \mathrm{dL}$ in children of 12-14 years and below $11.5 \mathrm{~g} / \mathrm{dL}$ in children aged 6-11 years [2]. Severe anemia is defined as $\mathrm{Hb}$ level below $7 \mathrm{~g} / \mathrm{dL}$ in children of 6-14 years of age. Moderate anemia is defined as $\mathrm{Hb}$ level $7 \mathrm{~g} / \mathrm{dL}-9.9$ $\mathrm{gm} / \mathrm{dL}$ in children of $6-14$ years of age. Mild anemia is defined as Hb level $10 \mathrm{~g} / \mathrm{dL}-11.4 \mathrm{~g} / \mathrm{dL}$ in children aged 
6-11 years and $\mathrm{Hb}$ level $10 \mathrm{~g} / \mathrm{dL}-11.9 \mathrm{~g} / \mathrm{dL}$ in children of 12-14 years of age.

Underweight: z-scores $<-2.00$ of the WHO median reference for weight-for age. Thinness: $\mathrm{z}$-scores $<-2.00$ of the WHO median reference for body mass index-for age. Stunting: $\mathrm{z}$-scores $<-2.00$ of the WHO median reference for height-for-age.

The age group of the children was dichotomized as 6-11 year and $12-14$ years $[19,20]$.

\section{Ethical considerations}

Ethical clearance was obtained from the Ethical Board of the Jimma University. Consent was taken from parents/guardians of the children and confidentiality was maintained.

\section{Results}

Sociodemographic and anthropometric characteristics of the study participants

A total of 423 children were selected, among whom complete response of the anthropometric measurements and blood samples were obtained from 404 students with the response rate of $95.6 \%$. The mean \pm SD age was $10.21 \pm 1.89$ years ranged between 6 and 14 years. From the total of 404 respondents, 291(72\%) children were 6-11 years old and 217(53.7\%) were females. As to the income, 103(25.5\%) of the parents earned a mean monthly income of below 500 ETB (US\$1 = 18.86 Ethiopian Birr). Regarding the educational status of the parents of the sampled children, $295(88.3 \%)$ of the fathers had formal education; 165(49.4\%) had attended secondary school; 78 (20.2\%) mothers of the children were illiterate (Table 1 ). As to the occupation of the parents of the children, 140 (34.7\%) fathers were civil servants and 193(47.8\%) mothers were housewives.

Concerning the results of the anthropometric measurements among anemic children, $13(8.6 \%)$ were thin, that is BMIFA $<-2 \mathrm{z}$-score, and the prevalence of stunting that is height for age $<-2 \mathrm{z}$-score was $12(7.9 \%)$.

\section{Prevalence of anemia}

The study population was divided into anemic and nonanemic groups. The anemic group was further classified into mild, moderate and severe anemia. The proportion of children with anemia was $152(37.6 \%)$ as shown in Tables 1 and 2 . The mean \pm SD hemoglobin was $11.59 \pm 1.97 \mathrm{~g} / \mathrm{dL}$. There was a significant difference in the mean \pm SD distribution of $\mathrm{Hb}$ levels among the age group of 6-11 years $(11.45 \pm 2.08 \mathrm{~g} / \mathrm{dL})$ and age group of $12-14$ years $(11.93 \pm$ $1.6 \mathrm{~g} / \mathrm{dL}), \mathrm{p}<0.05$. The mean $\pm \mathrm{SD}$ value of hemoglobin in male children was $11.39 \pm 1.94 \mathrm{~g} / \mathrm{dL}$, and in female children $11.76 \pm 1.97 \mathrm{~g} / \mathrm{dL}$ as shown in Table 2 .

The prevalence of anemia among the age group of 6-11 years was $118(40.5 \%)$, while it was $34(30.1 \%)$ among the group of 12-14 years. The prevalence of anemia in children whose father's are illiterate was $62.5 \%$, and that of children whose mothers are illiterate was $59 \%$. As per the monthly income of the families, the prevalence of anemia among children who belonged to families' earning an average monthly income of less than 500 ETB (=US\$26.5) was $64.1 \%$. The highest prevalence (69.2\%) of anemia was recorded in children whose parents were divorced. Therefore, the prevalence of anemia has a significant association with family income, parents' educational status and marital status with $\mathrm{p}<0.05$ (Table 1).

\section{Severity of anemia}

The grade of anemia was assessed by using the WHO's cutoff values. Regarding the severity, among anemic children, $73 / 152(48.0 \%)$ of them had mild anemia while 79/152(52.0\%) had moderate anemia. There was no single case of severe anemia observed in the present study.

\section{Association between anthropometric status, dietary factors and prevalence of anemia}

According to the WHO reference standard, taking -2 SD ( $\mathrm{Z}$ score) as a cutoff point [21], in this study children who fell below $\mathrm{Z}$ score of $-2 \mathrm{SD}$ of the indicators (stunted and thinness) were computed as $9.4 \%$ and $5.4 \%$, respectively.

The occurrence of anemia was $59.1 \%$ in children whose BMI for age is below $-2 Z$ score $(p=0.033)$. There was no statistically significant association between anemia and height for age $<-2 Z$ score (Table 3 ).

\section{Diet}

About $54.0 \%$ of the study samples reported that they consumed plant food at least once a day; $24.8 \%$ of them consume animal food at least once a week. The occurrence rate of anemia was significantly higher in children who take foods of both plant and animal sources less frequently $(\mathrm{p}=0.000)$ (Table 3).

\section{Correlates of anemia}

To control the effect and predict the most important determinants of anemia, a stepwise logistic regression analysis was performed. In the model, the independent variables that had marginal and significant associations with anemia in the chi-square tests were computed. This model showed that mothers' educational level, low family income, inadequate intake of plant and animal food were found to be significantly associated with anemia (Table 4).

\section{Discussion}

The criteria for determining the presence of anemia, as recommended by the World Health Organization (WHO), are based on hemoglobin cutoff values for age and sex with 
Table 1 Association between sociodemographic variables and anemia among school children, $n=404$

\begin{tabular}{|c|c|c|c|c|c|}
\hline \multirow[t]{2}{*}{ Sociodemographic variables } & \multirow{2}{*}{$\begin{array}{c}\text { Total } n(\%) \\
n=404\end{array}$} & \multicolumn{2}{|c|}{ Anemia } & \multirow[t]{2}{*}{$x^{2}$} & \multirow[t]{2}{*}{ p-value } \\
\hline & & $\begin{array}{c}\text { Present } n(\%) \\
n=152\end{array}$ & $\begin{array}{c}\text { Absent } n(\%) \\
n=252\end{array}$ & & \\
\hline \multicolumn{6}{|l|}{ Sex } \\
\hline Male & 187(46.3) & $77(41.2)$ & $110(58.8)$ & 1.872 & 0.171 \\
\hline Female & $217(53.7)$ & 75(34.6) & $142(65.4)$ & & \\
\hline \multicolumn{6}{|l|}{ Age group } \\
\hline $6-11$ years & $291(72.0)$ & $118(40.5)$ & $173(59.5)$ & 3.796 & 0.51 \\
\hline $12-14$ years & $113(28.0)$ & $34(30.1)$ & $79(69.9)$ & & \\
\hline \multicolumn{6}{|l|}{ Religion } \\
\hline Muslim & $140(34.7)$ & $59(42.1)$ & $81(57.9)$ & & \\
\hline Orthodox & 199(49.3) & $69(34.7)$ & 130(65.3) & 2.281 & 0.516 \\
\hline Protestant & $61(15.1)$ & $22(36.1)$ & $39(63.9)$ & & \\
\hline Others* & $4(0.01)$ & $2(50.0)$ & $2(50.0)$ & & \\
\hline \multicolumn{6}{|l|}{ Ethnicity } \\
\hline Oromo & $162(40.1)$ & $72(44.4)$ & $90(55.6)$ & & \\
\hline Amhara & $87(21.5)$ & $30(34.5)$ & $57(65.5)$ & & \\
\hline Gurage & $19(4.7)$ & $8(42.1)$ & 11(57.9) & & \\
\hline Kefficho & $39(9.7)$ & $10(25.6)$ & $29(74.4)$ & & \\
\hline Dawro & $39(9.7)$ & 17(43.6) & $22(56.4)$ & 10.195 & 0.117 \\
\hline Yemme & $21(5.2)$ & $5(23.8)$ & $16(76.2)$ & & \\
\hline Others $* *$ & $37(9.2)$ & $10(27.0)$ & $27(73.0)$ & & \\
\hline \multicolumn{6}{|l|}{ Marital status (Parents) } \\
\hline Living together & $316(78.2)$ & 112(35.4) & 204(64.6) & & \\
\hline Divorced & $13(3.2)$ & $9(69.2)$ & $4(30.8)$ & 8.293 & 0.040 \\
\hline Widowed & $52(12.9)$ & $24(46.2)$ & 28(53.8) & & \\
\hline Separated & $23(5.7)$ & $7(30.4)$ & $16(69.6)$ & & \\
\hline \multicolumn{6}{|l|}{ Family size } \\
\hline$\leq 5$ & $236(58.4)$ & $86(36.4)$ & 150(63.6) & & \\
\hline$>5$ & 168(41.6) & $66(39.3)$ & $102(60.7)$ & 0.338 & 0.561 \\
\hline \multicolumn{6}{|l|}{ Educational level (Fathers) } \\
\hline Illiterate & $16(4.0)$ & $10(62.5)$ & $6(37.5)$ & & \\
\hline Read and write & $23(5.7)$ & $5(21.7)$ & 18(78.3) & 16.138 & 0.003 \\
\hline Primary level & $91(22.5)$ & $44(48.4)$ & $47(51.6)$ & & \\
\hline Secondary level & 165(40.8) & $52(31.5)$ & $113(68.5)$ & & \\
\hline Tertiary level & $39(9.7)$ & 10(25.6) & 29(74.4) & & \\
\hline Missed & $70(17.3)$ & & & & \\
\hline \multicolumn{6}{|l|}{ Educational level (Mothers) } \\
\hline Illiterate & $78(19.3)$ & $46(59.0)$ & $32(41.0)$ & & \\
\hline Read and write & $42(10.4)$ & $29(69.0)$ & 13(31.0) & 58.777 & 0.000 \\
\hline Primary level & $105(26.0)$ & $38(36.2)$ & $67(63.8)$ & & \\
\hline Secondary level & 139(34.4) & $24(17.3)$ & 115(82.7) & & \\
\hline Tertiary level & $22(5.4)$ & $6(27.3)$ & $16(72.7)$ & & \\
\hline Missed & $18(4.5)$ & & & & \\
\hline
\end{tabular}


Table 1 Association between sociodemographic variables and anemia among school children, $\mathbf{n}=404$ (Continued)

\begin{tabular}{|c|c|c|c|c|c|}
\hline \multicolumn{6}{|c|}{ Monthly income (ETB) ${ }^{*}$} \\
\hline$<500$ & 103(25.5) & $66(64.1)$ & $37(35.9)$ & \multirow{5}{*}{58.033} & \multirow{5}{*}{0.000} \\
\hline $500-999$ & 139(34.4) & $56(40.3)$ & 83(59.7) & & \\
\hline 1000-1499 & $88(21.8)$ & $17(19.3)$ & $71(80.7)$ & & \\
\hline 1500-1999 & $36(8.9)$ & $9(25.0)$ & $27(75.0)$ & & \\
\hline$>2000$ & $38(9.4)$ & $4(10.5)$ & $34(89.5)$ & & \\
\hline \multicolumn{6}{|c|}{ Occupation (Fathers) } \\
\hline Farmer & $32(7.9)$ & $15(46.9)$ & $17(53.1)$ & & \\
\hline Merchant & $47(11.6)$ & $7(14.9)$ & $40(85.1)$ & & \\
\hline Civil servant & 140(34.7) & $53(37.9)$ & $87(62.1)$ & & \\
\hline Hand craft & $65(16.1)$ & $18(27.7)$ & $47(72.3)$ & \multirow[t]{4}{*}{22.113} & \multirow[t]{4}{*}{0.000} \\
\hline Daily laborer & $28(6.9)$ & $17(60.7)$ & $11(39.3)$ & & \\
\hline Others*** & $22(5.4)$ & $11(50.0)$ & $11(50.0)$ & & \\
\hline Missed & $70(17.3)$ & & & & \\
\hline \multicolumn{6}{|c|}{ Occupation (Mothers) } \\
\hline Merchant & $78(19.3)$ & $17(21.8)$ & $61(78.2)$ & & \\
\hline Civil servant & $69(17.1)$ & $19(27.5)$ & $50(72.5)$ & \multirow{5}{*}{17.913} & \multirow{5}{*}{0.001} \\
\hline House wife & 193(47.8) & $86(44.6)$ & 107(53.4) & & \\
\hline Daily labor & $20(5.0)$ & $11(55.0)$ & $9(45.0)$ & & \\
\hline Others ${ }^{* * * *}$ & $26(6.4)$ & $10(38.5)$ & $16(61.5)$ & & \\
\hline Missed & $18(4.5)$ & & & & \\
\hline
\end{tabular}

*Jehovah witness, Catholic. **Welita, Hadiya, Kembata, Silttia, Tigre, ${ }^{*}$ US $\$ 1=18.86$ Ethiopian Birr (ETB) according to the current exchange rate. ${ }^{* * * W a i t e r, ~ F a c t o r y ~}$ worker, guard, retired. ${ }^{* * *}$ Waiter, Farmer, Factory worker, Hand craft, retired.

an additional epidemiological criterion for assessing the severity and magnitude of the problem.

Measurement of hemoglobin level is a vital physiological parameter that helps diagnose the extent and severity of anemia, polycythemia as well as other diseases of red blood cells. The magnitude of anemia determined in this study (37.6\%) is considered as a moderate public health problem according to World WHO standards [2].

The present finding is in agreement with those of related studies done in developing countries. The prevalence of anemia was $39.1 \%$ as it was done on 271 school-

Table 2 Distribution of hemoglobin $(\mathrm{Hb})$ level in different sex and age group among school children, $n=404$

\begin{tabular}{lccccc}
$\begin{array}{l}\text { Sex \& age } \\
\text { in years }\end{array}$ & $\begin{array}{c}\text { Total } \\
\mathbf{N}(\%)\end{array}$ & $\begin{array}{c}\text { Hb (g/dL) } \\
\text { Mean } \pm \text { SD }\end{array}$ & $\mathbf{t}$ & $\begin{array}{c}\text { Cl } \\
\mathbf{9 9 5} \%)\end{array}$ & p-value \\
\hline Sex: & & & & & \\
$\quad$ Male & $187(46.3)$ & $11.39 \pm 1.94$ & 1.89 & $-0.013,0.75$ & 0.058 \\
$\quad$ Female & $217(53.7)$ & $11.76 \pm 1.97$ & & & \\
Age: & & & & & \\
$\quad 6-11$ & $291(72)$ & $11.45 \pm 2.08$ & 2.432 & $0.089,0.855$ & 0.016 \\
$12-14$ & $113(28)$ & $11.93 \pm 1.60$ & & & \\
Total & $404(100)$ & $11.59 \pm 1.97$ & & & \\
\hline
\end{tabular}

age children (age range: 7-14 years) in Asendabo Town, Southwest of Ethiopia [22]. It was $39.4 \%$ of 531 school-age children in Cote Divoire [23]; $36.9 \%$ in a group of 250 school-age children in Leyte, Philippines [24] and 36.4\% among Vietnamese school age children [25] as determined by the same techniques. The result of this study also revealed that the prevalence rates of mild and moderate anemia were $18 \%$ and $19.6 \%$, respectively. No single case of severe anemia $(\mathrm{Hb}<7 \mathrm{~g} / \mathrm{dL})$ was detected in this study.

In the present study, mothers' educational level and average monthly income were found to be important determinants of anemia. Low level of mothers' education may affect children's nutritional status negatively, and low income limits the type and amount of food available. In line with this finding, Mohamed et al. [26], Alemayehu [22], Jemal and Rebecca [27], Kaya et al. [28] and Bassam [29] reported that mothers' educational level and low family income were found important determinants of anemia. Similarly, studies conducted on school-age children show the relationship between occurrence rate of anemia and family size [29] and anthropometric status of the children [29,30]. Additionally, father's working status was found to be an important correlate of anemia as evidenced by studies done on 256 children (age range: 2 to 15 years) of Um-unnasser Village, Gaza [29] and in a group of 1295 


\begin{tabular}{|c|c|c|c|c|c|c|c|}
\hline \multirow[t]{2}{*}{ Variables } & \multirow[t]{2}{*}{ Total N(\%) } & \multicolumn{2}{|c|}{ Anemia } & \multirow[t]{2}{*}{$x^{2}$} & \multirow[t]{2}{*}{ p-value } & \multirow[t]{2}{*}{ COR } & \multirow[t]{2}{*}{$95 \% \mathrm{Cl}$} \\
\hline & & Absent $\mathrm{N}(\%)$ & Present $\mathrm{N}(\%)$ & & & & \\
\hline \multicolumn{8}{|l|}{ BMI for age $<-2 Z$ score } \\
\hline Yes & $22(5.4)$ & $9(3.6)$ & 13(8.6) & 4.569 & 0.033 & 0.39 & $0.16,0.95$ \\
\hline No & 382(94.6) & 243(96.4) & 139(91.4) & & & 1.00 & \\
\hline \multicolumn{8}{|l|}{ Height for age $<-2 Z$ score } \\
\hline Yes & $38(9.4)$ & $26(10.3)$ & $12(7.9)$ & 0.653 & 0.419 & 1.34 & $0.65,2.74$ \\
\hline No & 366(90.6) & 226(89.7) & 140(92.1) & & & 1.00 & \\
\hline \multicolumn{8}{|c|}{ Consumption of food from plant source } \\
\hline Less than once a day & $186(46)$ & $76(30.2)$ & $110(73.4)$ & 67.99 & 0.000 & 0.16 & $0.10,0.25$ \\
\hline Once a day or more & $218(54)$ & 176(69.8) & $42(27.6)$ & & & 1.00 & \\
\hline \multicolumn{8}{|c|}{ Consumption of food from animal source } \\
\hline Less than once a week & $304(75.2)$ & $167(66.3)$ & 137(90.1) & 28.98 & 0.000 & 0.21 & $0.11,0.38$ \\
\hline Once a week or more & $100(24.8)$ & $85(33.7)$ & 15(9.9) & & & 1.00 & \\
\hline
\end{tabular}

school girls (age range: 6 to 18 years) in Ahmedabad city, Slums [30].

In the present study, about half of the children with anemia had lower intake of foods from animal sources, which is a source of heme iron. There are two forms of dietary iron: non-heme and heme iron. Non-heme iron takes the simplest form of free iron atoms such as ferric $(\mathrm{Fe} 3+)$ or ferrous $(\mathrm{Fe} 2+)$ iron. Non-heme iron is obtained from foods such as grains, pulses, legumes, fruits and vegetables [7]. In most populations throughout the world, non-heme iron is the main form of dietary iron. Heme iron is well absorbed in the intestine better than non-heme food obtained from plant sources. The finding of the present study indicated that more than half of the children who had anemia were eating food of plant source less frequently than non-anemic children. This dietary pattern would also result in low level of zinc and iron, which was found to be a strong predictor of hemoglobin level as studied in a group of 99 pregnant women [31] and in a group of 970 reproductive age women [27] in Ethiopia. A study conducted on pre-school children in Northern Ethiopia, Mekele, showed that the cultural food Teff-Enjera, which contains high amount of iron but bioavailability, was restricted because the type of iron is non-heme iron and there is an inadequate vitamin $C$, which reduces the absorption of iron [32]. Additionally, the major components of the diet in young children in developing countries are cereals and roots, which are not favorable for iron absorption as compared with meat and fish [33]. The present finding suggests high prevalence of anemia based on the fact that low level of $\mathrm{Hb}$ among school-age children probably due to dietary factors, inadequate consumption of animal food as mentioned above. Furthermore, reports of Djokic et al. [13] Kaya et al. [28] and Tiwari [34] show irregular consumption of meat and vegetable were found to be important correlates of anemia among school-age children. This fact supports the finding of this study.

Although not included in the present study, additional factors that may contribute to anemia in this population could be infection with intestinal parasites such as schistosomiasis, helminthes (hookworm in particular) and malaria.

\section{Conclusion}

The prevalence of anemia among school-age children (6-14 years old) in Jimma Town was high (37.6\%). This study also showed that mild and moderate levels of anemia were found to be $18 \%$ and $19.6 \%$ respectively, while no single case of severe anemia observed in the present study. It was established that occurrence of anemia is directly correlated with parents' income and maternal literacy status. Children whose maternal education was limited to reading, and writing and children who were from families earning an average monthly income of less than 500 ETB (=US \$26.5) were more likely to be affected by anemia. Participants who consumed animal and plant foods less frequently were more likely to develop anemia than that of more frequent users of these foods. This shows that the problem of anemia is linked with food insecurity because of economic constraints in the community.

Therefore, poverty alleviation and improving the economic status of the society is a crucial strategy to reduce the prevalence of anemia. General adult education to parents and health education to the community are also important strategies to reduce the burden of anemia. Consumer education is also recommended to encourage the use of diversified diets including iron-rich foods and fruits that contain vitamin $\mathrm{C}$ that enhances iron absorption. Additional studies are needed on micronutrients 
Table 4 Multivariate logistic regression analysis showing predictors of anemia among school children, $n=404$

\begin{tabular}{|c|c|c|c|c|c|}
\hline Variables & B & S.E & p-value & AOR & $95 \% \mathrm{Cl}$ \\
\hline \multicolumn{6}{|l|}{ Age } \\
\hline $6-11$ years & 0.279 & 0.355 & 0.432 & 1.322 & $(0.659,2.649)$ \\
\hline $12-14$ years & 0.0 & & & 1.00 & \\
\hline \multicolumn{6}{|l|}{ Marital status (family) } \\
\hline Living together & 0.0 & & & 1.00 & \\
\hline Widowed & 0.583 & 0.573 & 0.102 & 1.791 & $(0.890,3.604)$ \\
\hline Separated & 0.225 & 0.239 & 0.695 & 1.252 & $(0.407,3.850)$ \\
\hline \multicolumn{6}{|l|}{ Educational level (Father) } \\
\hline Illiterate & 1.026 & 0.955 & 0.283 & 2.790 & $(0.429,18.122)$ \\
\hline Read and write & -1.349 & 0.922 & 0.143 & .260 & $(0.043,1.580)$ \\
\hline Primary level & 0.020 & 0.643 & 0.976 & 1.020 & $(0.289,3.593)$ \\
\hline Secondary level & 0.001 & 0.565 & 0.998 & 1.001 & $(0.331,3.031)$ \\
\hline Tertiary level & 0.0 & & & 1.00 & \\
\hline \multicolumn{6}{|l|}{ Educational level (Mother) } \\
\hline Illiterate & 0.879 & 0.563 & 0.119 & 2.409 & $(0.799,7.268)$ \\
\hline Read and write & 1.531 & 0.615 & 0.013 & 4.621 & $(1.383,15.439)$ \\
\hline Primary level & 0.107 & 0.550 & 0.845 & 1.113 & $(0.379,3.274)$ \\
\hline Secondary level & -0.488 & 0.555 & 0.380 & .614 & $(0.207,1.824)$ \\
\hline Tertiary level & 0.0 & & & 1.00 & \\
\hline \multicolumn{6}{|c|}{ Average monthly income (ETB) ${ }^{*}$} \\
\hline$<500$ & 1.594 & 0.782 & 0.042 & 4.925 & $(1.063,22.820)$ \\
\hline 500-999 & 1.230 & 0.695 & 0.077 & 3.421 & $(0.876,13.361)$ \\
\hline 1000-1499 & 0.423 & 0.686 & 0.538 & 1.526 & $(0.398,5.857)$ \\
\hline 1500-1999 & 0.645 & 0.761 & 0.397 & 1.905 & $(0.429,8.461)$ \\
\hline$>2000$ & 0.0 & & & 1.00 & \\
\hline \multicolumn{6}{|l|}{ Occupation (Father) } \\
\hline Farmer & 0.319 & 0.725 & 0.660 & 1.375 & $(0.332,5.691)$ \\
\hline Merchant & -0.090 & 0.794 & 0.910 & .914 & $(0.193,4.335)$ \\
\hline Civil servant & 0.323 & .629 & 0.608 & 1.381 & $(0.403,4.737)$ \\
\hline Hand craft & -0.050 & 0.656 & 0.940 & .952 & $(0.263,3.445)$ \\
\hline Daily labor & 0.421 & 0.760 & 0.580 & 1.523 & $(0.344,6.749)$ \\
\hline Others ${ }^{* * *}$ & 0.0 & & & 1.00 & \\
\hline Occupation (Mother) & & . & & & \\
\hline Merchant & -0.192 & 848 & 0.820 & .825 & $(0.157,4.344)$ \\
\hline Civil servant & 0.747 & 0.857 & 0.383 & 2.112 & $(0.393,11.335)$ \\
\hline House wife & 0.692 & 0.718 & 0.335 & 1.999 & $(0.489,8.161)$ \\
\hline Daily labor & 1.127 & 1.088 & 0.300 & 3.087 & $(0.366,26.017)$ \\
\hline Others ${ }^{* * * *}$ & 0.0 & & & 1.00 & \\
\hline \multicolumn{6}{|l|}{ BMI for age $<-2 Z$ score } \\
\hline Yes & 0.207 & 0.658 & 0.754 & 1.229 & $(0.338,4.466)$ \\
\hline No & 0.0 & & & 1.00 & \\
\hline \multicolumn{6}{|c|}{ Consumption of food from plant source } \\
\hline Less than once a day & 1.347 & 0.317 & 0.000 & 3.847 & $(2.068,7.157)$ \\
\hline Once a day or more & 0.00 & & & 1.00 & \\
\hline \multicolumn{6}{|c|}{ Consumption of food from animal source } \\
\hline Less than once a week & 863 & 420 & 0.040 & 2.370 & $(1.040,5.402)$ \\
\hline Once a week or more & 0.0 & & & 1.00 & \\
\hline
\end{tabular}

***Waiter, factory worker, guard, retired. ***Waiter, farmer, factory worker, hand craft, retired.

${ }^{\sharp}$ US $\$ 1=18.86$ Ethiopian Birr (ETB) according to the current exchange rate. 
deficiency, parasite infections, hereditary disorders and environmental pollutants.

\section{Limitation of the study}

This study has several limitations. It was done based on cross-sectional data, and we therefore, could not establish a cause effect relationship. We did a descriptive study that reports the prevalence and severity of anemia in general. The study lacks detailed investigation of the morphological appearance of red blood cells to differentiate anemia due to vitamin $B_{12}$ and folic acid deficiencies from anemia due to iron deficiency. A study on the prevalence of iron deficiency anemia is being conducted by the team and will be reported soon. Stool test was not done to diagnose intestinal parasitic infection that contributes to anemia.

\section{Competing interests}

The authors declare that they have no competing interests.

\section{Authors' contributions}

SA: involved in the preparation of the study design, participated in data collection, data entry and data analysis as well as manuscript preparation. AM: involved in the research proposal organization, data collection and data analysis and manuscript preparation. LH: involved in the preparation of the study design, data analysis and manuscript preparation. All authors read and approved the final draft of the manuscript.

\section{Acknowledgement}

The authors are grateful to Jimma University for its research support.

\section{Author details}

'Lecturer (MSc, Physiologist), Department of Medicine, College of Medicine and Health Sciences, Ambo University, Ambo, Ethiopia. ${ }^{2}$ Associate Professor (PhD, Physiologist), Department of Biomedical Sciences, College of Public Health and Medical Sciences, Jimma University, Jimma, Ethiopia. ${ }^{3}$ Assistant Professor (MD, Internist), Department of Internal Medicine, College of Public Health and Medical Sciences, Jimma University, Jimma, Ethiopia.

Received: 1 July 2013 Accepted: 8 January 2014

Published: 16 January 2014

\section{References}

1. DeMaeyer E, Adiels-Tegman M: The prevalence of anemia in the world. World Health Stat Q 1985, 38:302-316.

2. United Nations Children's Fund/United Nations University/WHO: Iron deficiency anaemia. Assessment, prevention and control. A guide for programme managers (WHO/NHD/01.3). Geneva: World Health Organization; 2001:15-31.

3. World Health Organization: The World Health Report 2002: Reducing risks, promoting healthy life. Geneva: World Health Organization; 2002:49-93.

4. Benoist B, McLean E, Cogswell M, Egli I, Wojdyla D: Worldwide prevalence of anemia 1993-2005. World Health Organization Global Database on Anemia. Geneva: World Health Organization; 2008:7-13.

5. Guesry GP: The role of nutrition in brain development. Prev Med 1998, 27:189-194.

6. United Nations, ACC/SCN: Controlling Iron Deficiency. Nutrition Policy Discussion. 9th edition. New York: United Nations; 1991:71.

7. Neumann CG, Bwibo NO, Murphy SP, Sigman M, Whaley S, Allen LH, et al: Animal source foods improve dietary quality, micronutrient status, growth and cognitive function in Kenyan school children: Background, study design and baseline findings. J Nutr 2003, 133:3941-3949.

8. Hall A, Roschnik N, Ouattara F, Toure I, Maiga F, Sacko M, Moestue H, Bendech MA: A randomised trial in Mali of the effectiveness of weekly iron supplements given by teachers on the haemoglobin concentrations of school children. Public Health Nutr 2002, 5:413-418.

9. Tatala SR, Kihamia CM, Kyungu LH, Svanberg U: Risk factors for anemia in school children in Tanga Region, Tanzania. Tanzan J Health Res 2008, 10(4):189-202.
10. Alaofè H, Zee J, Dossa R, O'Brien HT: Education and improved iron intakes for treatment of mild iron-deficiency anemia in adolescent girls in southern Benin. Food Nutr Bull 2009, 30:24-36.

11. Kikafunda JK, Lukwago FB, Turyashemererwa F: Anemia and associated factors among under-fives and their mothers in Bushenyi district, western Uganda. Public Health Nutr 2009, 12:2302-2308.

12. Hashizume M, Shimoda T, Sasaki S, Kunii O, Caypil W, Dauletbaev D, et al: Anemia in relation to low bioavailability of dietary iron among schoolaged children in the Aral Sea region, Kazakhstan. Int J Food Sci Nutr 2004, 55:37-43.

13. Djokic D, Radojicic ZL, Rakic L: Risk factors associated with anemia among Serbian school-age children 7-14 years old: results of the first national health survey. Hippokratia 2010, 14(4):252-260.

14. Ramalingaswami $\mathrm{V}$, Jonsson U, Rhode J: Malnutrition: a south Asian enigma. In Malnutrition in South Asia: a regional profile. Edited by Gillespie SR. Kathmandu: Rosa Publication; 1997:11-22.

15. Central Statistical Agency (CSA): 2007 Population and Housing Census of Ethiopia administrative report. Addis Ababa: The Projected result for Oromia Region; 2010.

16. Haidar J, Abate G, Kogi-Makau W, Sorensen P: Risk factors for child under-nutrition with a human rights edge in rural villages of North Wollo, Ethiopia. East Afr Med J 2005, 82:625-630.

17. The WHO child growth standards: World Health Organization 2009 [Accessed in April 01, 2013]. Available in: http://www.who.int/growthref/en/.

18. WHO AnthroPlus for personal computers manual: Software for assessing growth of the world's children and adolescents 2009. [Accessed in April 07, 2013]. Available in: http://www.who.int/growthref/tools/en/.

19. Amare B, Moges B, Fantahun B, Tafess K, Woldeyohannes D, Yismaw G, et al: Micronutrient levels and nutritional status of school children living in Northwest Ethiopia. Nutrition J 2012, 11:108.

20. Lindsay A, de Bruno B, Omar D, Richard H: WHO's Guidelines on food fortifications and micronutrient developed. Geneva: $\mathrm{HHO}$ and FAO; 2006

21. Mercedes DO, Onyango WA, Borghi E, Siyam A, Nishida C, Siekmann J: Development of a WHO growth reference for school-aged children and adolescents. Bull World Health Organ 2007, 85(9):660-667.

22. Alemayehu N: Prevalence of hook worm infection and its association with anemia among students of Asendabo elementary school. Abstract, student research project, CBE program. 2nd edition. Jimma, Ethiopia: Jimma University; 2005:209.

23. Zimmermann MB, Molinari L, Staubli-Asobayire F, Hess SY, Chaouki N, Adou P, et al: Serum transferrin receptor and zinc protoporphyrin as indicators of iron status in African children. Am J Clin Nutr 2005, 81:615-623.

24. Leenstra T, Acosta LP, Langdon GC, Manalo DL, Olveda RM, McGarvey ST, et al: Schistosomiasis japonica, anemia, and iron status in children, adolescents, and young adults in Leyte, Philippines. Am J Clin Nutr 2006, 83:371-379.

25. Thi LH, Brouwer ID, Burema J, Nguyen KC, Kok FJ: Efficacy of iron fortification compared to iron supplementation among Vietnamese schoolchildren. Nutr J 2006, 5:32.

26. El Mohamed H, Ahmed O, Youssef A, Stephane R, Khalid D, Abdelkader S: Iron deficiency and anaemia in rural school children in a coastal area of Morocco. Pak J Nutr 2008, 7(3):400-403.

27. Jemal AH, Rebecca SP: Iron deficiency anemia is not a rare problem among women of reproductive ages in Ethiopia: a community based cross sectional study. BMC Blood Disorders 2009, 9(7):1-8. http://www. biomedcentral.com/1471-2326/9/7.

28. Kaya M, Pehlivan E, Aydoğdu I, Genc M, Gunes G, Kaya E, et al: Iron deficiency anaemia among students of Two primary schools at different socioeconomic conditions in Malatya, Turkey. Inönü Üniversitesi Tip Fakültesi Dergisi 2006, 13(4):237-242.

29. Bassam F, AL-ZAIN: Impact of socioeconomic conditions and parasitic infection on hemoglobin level among children in Um-unnasser village, Gaza Strip. Turk J Med Sci 2009, 39(1):53-58.

30. Verma A, Rawal SV, Kedia G, Kumar D, Chauhan J: Factors influencing anaemia among girls of school going age (6-18 years) from the Slums of Ahmedabad city. Ind J Commun Med 2004, 29(1):25-26.

31. Yewelsew A, Gibson RS, Stabler S, Allen RH, Westcott JE, Stoecker BJ, et al: Zinc, gravida, infection, and iron, but not vitamin B-12 or folate status, predict hemoglobin during pregnancy in Southern Ethiopia. J Nutr 2008, 138:581-586. 
32. Adish AA, Esrey SA, Gyorkos TW, Johns T: Risk factors for iron deficiency anaemia in preschool children in northern Ethiopia. Public Health Nutr 1998, 2(3):243-252.

33. Fleming AF, Werblihska B: Anemia in childhood in Guinea Savane of Nigeria. Ann Trop Paediatr 1982, 2:161-173.

34. Tiwari K, Seshadri S: The prevalence of anemia and morbidity profile among school going adolescent girls of urban Kathmandu, Nepal. J Nep Med Assoc 2000, 39:319-325.

doi:10.1186/2052-1839-14-3

Cite this article as: Assefa et al:: Prevalence and severity of anemia among school children in Jimma Town, Southwest Ethiopia. BMC

Hematology 2014 14:3.

\section{Submit your next manuscript to BioMed Central and take full advantage of:}

- Convenient online submission

- Thorough peer review

- No space constraints or color figure charges

- Immediate publication on acceptance

- Inclusion in PubMed, CAS, Scopus and Google Scholar

- Research which is freely available for redistribution 